\title{
TUAN GURU HAJI MUHAMMAD HUSAIN A. KALAM TUASIKAL: MENDAYUNG MENANTANG BADAI MALUKU
}

\section{Tuan Guru H. Muhammad Husain A.Kamal Tuasikal: Rows Challenging Maluku Sudden Storm}

\author{
Idham \\ Balai Penelitian dan Pengembangan Agama Makassar \\ Kantor: Jl. A.P. Pettarani No. 72 Makassar \\ Email: idbodi@yahoo.co.id
}

Naskah diterima tanggal 2 Juni 2014. Naskah direvisi tanggal 2 September 2014. Naskah disetujui tanggal 7 Oktober 2014.

\begin{abstract}
Abstrak
Penelitian ini bertujuan untuk menulis biografi singkat ulama yang menjadi sasaran penelitian. Adapun ulama sasaran penelitian ini adalah seorang tokoh pendidikan sekaligus seorang pejuang Kemerdekaan Republik Indonesia. Beliau adalah Tuan Guru Haji Muhammad Husain A. Kalam Tuasikal, yang lebih dikenal dengan nama Tuan Guru Husain Tuasikal. Beliau lahir di negeri Pelaw Pulau Haruku pada tanggal 10 Desember 1918 dan meninggal dunia dalam usia 64 tahun, yakni pada tanggal 28 Oktober 1982 di Ory negeri Pelaw dan juga dimakamkan di sana. Sebagai seorang tokoh pendidikan, beliau telah meninggalkan yayasan Nadil Ulum dan Madrasah yang sama dengan nama yayasan tersebut. Madrasahmadrasah tersebut tersebar pada lima negeri di Maluku Tengah. Sebagai seorang yang nasionalis, beliau adalah pendiri sekaligus sebagai sekretaris PRIMA (Pemuda Republik Indonesia Maluku). Atas jasajasanya dalam bidang pendidikan dan tokoh pejuang, pemerintah memberikan penghargaan sebagai tokoh pendidikan Indonesia mewakili Provinsi Maluku pada tahun 1978 dan sebagai anggota legiun veretan Republik Indonesia.
\end{abstract}

Kata kunci: biografi ulama, ulama Maluku, tokoh pendidikan, tokoh pejuang, Tuan Guru Husain Tuasikal

\begin{abstract}
This research intents on writing short biographies of scholars who become the target of research. The goal of scholars in this research is a education prominent figure all at once a Indonesian Independence fighter. He was Tuan Guru Haji Muhammad Husain A. Kalam Tuasikal, better known by the name of Tuan Guru Husain Tuasikal. He was born in the country of Pelaw in Haruku Island on December $10^{\text {th }}, 1918$ and died at the age of 64 years old, on the date of October $28^{\text {th }}, 1982$ at Ory, the country of Pelow and also was laid to rest there. As an educational leader, he had left the foundation of Nadhil Ulum and Islamic School has as the same name as the foundation name. Islamic schools are scattered in the five countries in Central of Maluku. As a nationalist, he was a founder all at once secretary of the PRIMA (Pemuda Republik Indonesia Maluku, Youth of the Republic of Indonesia Maluku). For his services in the education sector and hero, the government gave the award for Indonesian education leaders representing the Province of Maluku in 1978 and as a member of the legion veretan Republic of Indonesia .
\end{abstract}

Keywords: biography of ulama, ulama (Clerics) of Maluku, education prominent figure, Tuan Guru Husain Tuasikal 


\section{PENDAHULUAN}

$\mathrm{D}$ ata Kementerian Agama wilayah provinsi Maluku tersebut, tampak bahwa ada dua agama utama di Provinsi Maluku yakni Islam dan Kristen. Penyebaran dan perkembangan kedua agama ini tidaklah mengherankan karena kedua agama ini adalah agama wahyu dan agama dakwah (misi). Hal lain yang menjadi penyebab kedua agama tersebut berkembang pesat di Maluku, karena Maluku merupakan tujuan para pedagang, yang selain berdagang juga menyebarkan agama mereka. Agama Islam dibawa pedagang Arab, sementara Kristen dibawa kolonial Belanda, Portugis, dan Spanyol.

Islam sebagai agama wahyu dan dakwah yang disampaikan melalui utusan-Nya, Nabi Muhammad saw. Semasa hidup Rasulullah Muhammad saw masih hidup, tugas dakwah dalam penyebaran agama ini ada di pundak beliau. Tugas dakwah dalam menyebarkan Islam sepeninggal beliau merupakan tanggung jawab setiap umat Islam. Itulah sebabnya, perkembangan Islam pada suatu daerah tidak terlepas dari umat Islam itu sendiri terutama para ulama. Para ulama adalah pengembang risalah, sebagai pengembang risalah, ulama mempunyai makam atau kedudukan yang sangat tinggi, baik dalam masyarakat maupun mengakuan ajaran agama itu sendiri. Keberadaannya dinyatakan oleh Rasulullah saw sebagai warasatul anbiya, pewaris para nabi dalam menyampaikan misi Islam, amar ma'ruf nahi munkar.

Ulama adalah peran multi dimensi dalam pembinaan umat pada setiap generasi dan masa. Bahkan setiap Negara atau daerah selalu ada muncul tokoh agama atau ulama. Begitu urgennya peran ulama, sehingga di banyak daerah, sosio-history masyarakatnya sering dilekatkan atau disandarkan pada ketokohan seorang atau beberapa orang ulama. Begitu pentingnya posisi ulama, sehingga masyarakat setempat memberikan gelar kehormatan yang bersifat kultural, semisal di provinsi Maluku, masyarakat memberikan gelar kepada ulama dengan sebutan kiai, ustas, tuan guru, dan tete guru.

Pemaknaan ulama sebagai "guru" sebagai tempat belajar tentang agama berbeda dengan pengertian guru dalam pengertian umum. Disini pemaknaan ulama melekat beberapa kualifikasi yakni kapasitas keilmuan, pengamalan dan akhlak
(Abd. Kadir Ahmad, 2009: 177-361). Kapasitas keilmuan mencakup latar belakang keilmuan berasal dari pesantren, penguasaan kitab kuning, wawasan yang luas dan layak menjadi rujukan dalam mengambil keputusan. Sedang aspek pengamalan meliputi fungsi-fungsi sosial dalam hal penyatuan ummat dan pengayom, konsisten dan memiliki jamaah serta fungsi-fungsi lain untuk kemaslahatan ummat. Pada aspek akhlak, penekanannya pada kharisma, tawadhu, jujur, amanah dan akrab dengan tradisi sarung serta ciri-ciri lainnya. Sehingga masyarakat memandang, ulama adalah satu sosok yang menjadi sentral dalam bidang pembinaan keagamaan, pembinaan moral, dan spiritual umat, agar umat senantiasa berada dalam koridor agama, senantiasa menjadi rahmat seru sekalian alam (rahmatan lil alamin).

Akan tetapi, ulama yang begitu banyak jasanya dalam menjaga dan memperbaiki moral bangsa belum banyak diungkap dalam bentuk tulisan. Pada hal dalam diri seorang tokoh ulama, banyak hal yang dapat dipetik dari kepribadian mereka, seperti: kegigihan dan keteguhan, keberanian, kesabaran, cara menyelesaikan masalah, dan lain sebagainya.

Bertolak dari masalah tersebut, maka pada tahun 2010 Balibang Agama Makassar mengadakan penelitian dengan mengangkat judul Biografi Ulama dan Karya Tulisnya. Penelitian tersebut kemudian dibukukan dalam bentuk bunga rampai dengan judul Buah Pena Sang Ulama. Pada tahun 2012, penelitian tersebut dilanjutkan dengan meneliti Ulama Perempuan dan Karya Tulisnya, dan pada tahun 2013, penelitian tersebut dilanjutkan lagi dengan judul biografi ulama di Kawasan Timur Indonesia.

Salah satu ulama di Kawasan Timur Indonesia adalah Tuan Guru H. M. Husain A. Kalam Tuasikal. Beliau adalah seorang pejuang kemerdekaan, pendiri yayasan Nadil Ulum Ory Kecamatan Pulau Haruku, kabupaten Maluku Tengah, Provinsi Maluku.

Berdasarkan pada latar belakang di atas, permasalahan yang diangkat dalam penelitian ini, adalah Bagaimana kehidupan dan peran dari Tuan Guru Haji Muhammad Husain A. Kalam Tuasikal?

\section{METODE PENELITIAN}

Penelitian ini merupakan penelitian deskreptif kualitatif yang berusaha menyusun Biografi singkat Ulama serta mendeskripsikan berbagai hal berkaitan 
dengannya sebagai informasi berharga untuk pengkajian atau pemanfaatan lebih lanjut. Teknik pengumpulan data yang dipergunakan adalah: a) Observasi terhadap lingkungan masyarakat sekitar ulama yang diteliti, terutama kehidupan keagamaannya, b) Wawancara dengan informan yang relevan, yakni yang memiliki informasi berharga tentang penelitian. Informan berasal dari keluarga atau kerabat (sasaran penelitian), tokoh masyarakat, dan anggota masyarakat lainnya, dan c) Studi pustaka dan dokumen yang berkaitan dengan penelitian. Karena penelitian ini merupakan peneltian kualitatif maka analisis data dilakukan dengan analisis kualitatif deskreptif dalam bentuk narasi.

Data yang dikumpulkan dalam penelitian ini mengenai data tentang identitas pribadi ulama yang diteliti meliputi: latar belakang keluarga, riwayat pendidikannya (formal dan nonformal), sikap keagamaannya, kegiatan dan aktivitasnya sebagai tokoh (agama, pendidik, dan lain-lain). Adapun lokasi penelitian Penelitian ini dilaksanakan di Ory Negeri Pelaw Kecamatan Pulau Haruku Kabupaten Maluku Tengah Provinsi Maluku.

\section{PEMBAHASAN}

\section{Setting penelitian: Maluku dan Islam}

Pada masa awal daerah jazirah kepulauan antara pulau Sulawesi dan Papua dikenal dengan nama Maluku. Nama ini pula yang dalam tambo Dinasti Tang dari Cina (618-906) disebut sebagai Ma-li-ki, dan buku Nagarakartagama (1365) menuliskannya dengan Maloko, sementara para pedagang Arab menamakannya Jazirah al-Mamluk (M. Adnan Amal, 2010). Maluku secara Internasional dikenal sebagai Mollucas, atau kawasan seribu pulau dan kepulauan rempah-rempah. Suku Bangsa Maluku secara teritOryal, kini terbagi dua provinsi, yakni Provinsi Maluku dan Provinsi Maluku Utara (Gagas Ulung, 2011:4).

Pada masa kekinian, secara geografis, Provinsi Maluku yang terdiri atas 11 kabupaten dan kota, merupakan sebuah provinsi yang berbentuk kepuluan, Bahkan Maluku, merupakan provinsi kepulauan terbesar di Indonesia, ada sekitar 559 pulau yang tersebar di provinsi yang namanya diambil dari bahasa Arab ini, yaitu jazirah almulk. Secara geografis, provinsi Maluku berada pada posisi 8'30' - 2'30 LS dan 125'20"-135'10" BT.
Dengan luas wilayah didominasi oleh perairan yaitu seluas 659.294,69 $\mathrm{Km} 2$ serta luas daratan 54.185 Km2. Wilayah Maluku di sebelah Utara berbatasan dengan Laut Seram serta Provinsi Maluku Utara dan Papua Barat, di sebelah Barat berbatasan dengan Provinsi Sulawesi Tengah, Sulawesi Tenggara dan laut Sulawesi. Sebelah Selatan berbatasan dengan Laut Banda, Samudera Indonesia, Timor Leste, dan Provinsi Nusa Tenggara Timur. Serta sebelah Timur berbatasan dengan laut Aru dan provinsi Papua. Kondisi Demografis, penduduk Provinsi Maluku pada tahun 2012 berjumlah 1.703.541 jiwa dengan kepadatan penduduk hanya $28 \mathrm{jiwa} / \mathrm{Km} 2$, dengan komposisi penganut agama yakni, Islam (982.070 orang), Kristen (552.584 orang), Katolik (159.920 orang), Hindu (8.122 orang), dan Buddha (845 orang) (Gagas Ulung, 2011: 125).

Penyebaran Islam atau masuknya Islam di Maluku tidak diketahui secara pesti (Rumahuru, 2012), sama halnya di daerah-daerah lain di nusantara. Membahas persoalan Islam di Maluku tentu tidak bisa dilepaskan dari konteks Nusantara secara keseluruhan, asal usul Islam di Maluku juga tidak kalah lebih sulit dan spekulatif (Dedi Djubaeli, 2011: 30). Ketiadaan bukti-bukti tertulis maupun prasasti atau bukti arkeologis pada umumnya telah menyebabkan sulit menetapkan secara akurat kapan agama Islam masuk ke Maluku (M. Adnan Amal, 2010: 235). Karena penyebaran Islam di seluruh Nusantara dilakukan melalui para pedagang, dapat diduga bahwa penyebaran agama ini mengikuti jalur-jalur niaga ketika itu, dengan sasaran utama kota-kota pantai dan bandar-bandar perniagaan. Permasalahan bagaimana, mengapa dan kapan penduduk Maluku mulai menganut agama Islam, tidak mudah disepakati secara bulat. Dari sejumlah premis kesejarahan, dapat disimpulkan bahwa orang-orang asing dari Asia-Arab, Gujarat, dan Cina yang berprofesi pedagang, berikut pedagangpedangang dari Jawa dan Melayu yang telah memeluk agama Islam, merupakan penyebar agama Islam di Maluku pada masa awalnya. Dari sekian banyak pendapat para ahli tentang masuknya Islam di Maluku, dapat diringkas: 1) menurut Pigafetta sekitar tahun 1469, 2) menurut Barros sekitar tahun 1430, dan Thome Pires antara 1420-1430 (M.Adnan Amal, 2010: 239).

Dari sekian banyak pendapat para ahli dengan alasan masing-masing setelah Islam dianut oleh 
penduduk Maluku, maka tugas dakwak tidak hanya diemban oleh pedangang (pendatang) namun tugas dakwah tersebut juga sudah menjadi tugas dari penduduk asli malku yang telah memeluk agama tersebut. Dari studi dokumentasi dan wawancara, peneliti memperoleh nama-nama ulama yang mereka sebut tuan guru, kiau, tete guru dan Ustad baik yang sudah meninggal maupun masih hidup. Adapun yang sudah meninggal, antara lain: Abdul Kadir Marasabessy, Abdul Rahman Khow, Abdul Rahman Marasabessy, Abdul Rahman Umarella, Abdul Syukur Rahimi Marasabessy, Abdullah King Koa, Abdullah Razak Ala Mudi, Ali Marasabessy, Ahmad Bantam, Ambarak, Amin Lestaluhu, Asy’ariy, Gaffar Thalib, Imam Rijali, Ishak Umarella, M.Nur HB. Latuconsina, Muhammad Husain Tua Sikal, Pati Puta, Payapo, Salim Hatta Payo, Syekh Ahmad B. Weres, Thayyib Lestaluhu, dan Usman Rumbia.

Selain ulama-ulama yang sudah meninggal tersebut, kalangan habaib juga mempunyai catatan para habaib yang berprofesi ulama dan guru di Maluku (khususnya Kota Ambon yang sudah meninggal), yaitu: Habib Salim bin Ali bin Syekh Abubakar, Habib Abdullah bin Abubakar Assagaf, Habib Abdullah bin Ali bin Thahir (Tulehu), Habib Abdullah bin Alwi Alaydrus, Habib Abdullah bin Husain Alhabsyi, Habib Abdullah bin Shaleh bin Hamzah Al Hamid, Habib Abdul Rahman bin Abdullah Assagaf, Habib Abdul Rahman bin Ahmad Jamalullail, Habib Abubakar bin Abdullah Assagaf, Habib Abubakar bin Ali bin Heyder Alhamid, Habib Abubakar bin Husain Alaydrus, Habib Abubakar bin Husain Assagaf, Habib Abubakar bin Muhsin bin Ghalib Alhamid, Habib Abubakar bin Salim Alhamid, Habib Abubakar bin Zen Alaydus, Habib Ahmad bin Hamid Alhamid, Habib Ahmad bin Salim bin Syekh Abubakar, Habib Ali bin Abubakar bin Salim Alhamid, Habib Ali bin Alwi Alaydrus, Habib Ali bin Hasan bin Heyder Alhamid, Habib Ali bin Muhammad al Attas (Larike), Habib Ali bin Salim bin Syekh Abubakar, Habib Alwi bin Abdullah Alaydrus, Habib Alwi bin Ali Laydrus, Habib Awad bin Hasan bin Idrus Alhamid, Habib Hadi bin Salim bin Syekh Abubakar, Habib Hasan bin Husain Alaydrus, Habib Hasan Bin Umar bin Buftaim, Habib Hud bin Alwi Alaydrus, Habib Husain bin Abdullah Alhabsyi, Habib Husain bin Abdul Rahman Jamalullail, Habib Husain bin
Ahmad Buftaim, Habib Husain bin Salim bin syekh Abubakar, Habib Husain binSegafbin Smith (Larike), Habib Idrus bin Muhammad Alhamid, Habib Idrus bin Abdullah Alhabsyi, Habib Muhammad bin Abdullah Alhabsyi, Habib Muhammad bin Ahmad bin Agil, Habib Muhammad bin Ali Alaydrus, Habib Muhsin bin Awad Alhamid, Habib Muhsin bin Hasan Alaydrus, Habib Muhsin bin Husain Alaydrus, Habib Muhsin bin Muhdar Assagaf, Habib Salim bin Husain Alhabsyi, Habib Salim bin Idrus bin Husain Alhamid, Habib Shahil bin Hasan bin Husain Jamalullail, Habib Shaleh bin Salim bin Syekh Abbakar, Habib Shaleh bin Umar Buftaim, Habib Syekh bin Muhsin Alhamid, Habib Umar bin Muhammad Alhamid, Habib Umar bin Saleh Abu Futaim, Habib Umar bin Salim bin Syekh Abubakar, Habib Umar bin Syekh bin Yahya, Ustadz Abubakar Alaydrus, Ustadz Abubakar bin Ali bin Yahya, Ustadz Hasan bin Muhsin bin Ghalib Alhamid, Ustadz Ahmad bin Hamid AlHamid, dll. (Lihat Dedi Djubaeli, dkk. 2011: 126-127)

Adapun ulama dan atau Ustadz di Provinsi Maluku yang masih hidup, antara lain: A.Madjid Makassar, Abd. Khalik Latuconsina, Abd. Rauf, Abdul Karim Marasabessy, Abdul Wahab Pol Poke, Abdullah Patilo, Ali Fauziy, Alwi Marasabessy, Fahri Husni Al Qathiriy, Hadi Basalamah, Halek Umamiti, Hamadi B. Ibrahim, Hasbullah T. Suta, Husen Maswara, Husen Sairiy, Idrus E Toekan, Ikram Ibrahim, Ismail ramadhan, Mahyuddin Latuconsina, Mohdar Yanlua, Muhammad Shadiq, Nasaruddin, Nur Tawainella, Sulaiman Rahman, dan Syaid Mudzakkir Assegaf.

Selain nama-nama tersebut, di Kota Ambon sendiri ada beberapa orang yang berprofesi sebagai dai atau muballigh. Ada sekira 86 orang yang tersebar nama-namanya dalam jadwal khutbah selama satu tahun. Penyebaran jadwal khutbah, ceramah Ramadhan, dilakukan oleh berbagai instansi dan organisasi Islam, seperti: organisasi dakwah Partai Keadilan Sejahtera (PKS), Kementerian Agama, IAIN Ambon, Masjid Al Fatah, BINTAL Pangdam XVI Pattimura (A. Mujadid Naya, 2011: 141). Jumlah 86 orang muballig di kota Ambon terasa sangat kurang untuk melayani penduduk sekitar 332.000 orang. Adapun kriteria mubaligh dan dai di Ambon sangatlah sederhana, yakni bagi mereka yang sudah dapat membaca ayat dan hadits serta dapat menyampaikannya di depan umum. 
Husain Tua Sikal: Lahir di Tengah Masyarakat Adat

Negeri Pelaw, adalah salah satu negeri dari 11 negeri Adat di Kecamatan Pulau Haruku Kabupaten Maluku Tengah. Bilakita di Ambon, ibukota Provinsi Maluku, misalnya kita berangkat di pasar Tradisional Mardika, hendak ke Pulau Haruku dapat ditempuh dengan naik mobil dari Ambon menuju utara pelabhan Tulehu. Dari pelabuhan Tulehu, kita akan menyeberangi selat Haruku dengan menggunakan speedboat yang berpenumpang 8 atau 12 orang. Kita akan diombang ambing kelombang sekita 25-35 menit menuju pelabuhan Wairiang Pulau Haruku. Pelabuhan Wairiang masuk dalam wilayah negeri Kailolo. Di Wairiang telah menunggu banyak ojek yang menawarkan jasa ke mana saja di Pulau Haruku. Dari Pelabuhan Wairiang menuju negeri Pelaw yang berjarak sekira $7 \mathrm{~km}$ dapat ditepuh 20 menit dengan naik ojek. Negeri Pelaw merupakan ibukota kecamatan Haruku, juga merupakan negeri yang terpadat penduduknya dibandingkan dengan negeri-negeri lain. Di negeri Pelaw inilah pada tanggal 10 Desember 1918 lahir seorang anak bangsa, yang oleh kedua orang tuanya diberi nama Muhammad Husain.

Nama Lengkapnya adalah Tuan Guru Haji Muhammad Husain A. Kalam Tuasikal (selanjutnya hanya disebut Husain Tuasikal) adalah anak kedua dari lima bersaudara (Sitima Tuasikal, Nafsiah Tuasikal, Umar Tuasikal, dan Nurul Huda Tuasikal). Terlahir dari dua marga atau fam (familienam) yang berbeda, yakni bapak bernama Abdul Kalam dengan fam Tuasikal dan Ibu bernama Sarafiah dengan fam Latuconsina. Dalam sistem kekeluargaan terdapat tiga istilah, yaitu Patrilineal, matrilineal, dan bilateral. Istilah patrilineal merupakan sistem kekeluargaan yang menarik garis keturunan dari keturunan bapak. Matrilineal adalah sistem garis keturunan yang menarik garis keturunan dari garis keturunan ibu. Sedangkan bilateral sendiri tidak terdapat dominasi antara bapak maupun ibu (Kamannto Snarto, 2004: 65). Patrilineal adalah sesuatu yang telah menjadi kebiasaan dalam kehidupan masyaarakat pada umumnya yang mengatur alur keturunan berasal dari pihak bapak yang hampir dianut oleh sebahagian besar masyarakat Maluku, termask keluarga Muhammad Husain. Karena keluarga ini menganut patrilineal, maka nama lengkap dari Muhammad Husain adalah Haji Muhammad Husain A. Karim Tuasikal, yang lebih dikenal dengan nama Tuan Guru Husain Tuasikal.

Negeri Pelaw, adalah negeri yang elok. Di depan tampak pulau Seram yang dibatasi oleh lautan, melihat ke timur tampak Pulau Maluku, dan melihat ke kanan tampak Pulau Saparua. Di bibir pantai terdapat benteng Hoorn, sebuah benteng peninggalan Portugis.

Masyarakat negeri Pelaw mempunyai identitas yang menonjol di antara negeri-negeri di Pulau Haruku, Pelaw dikenal dengan Islam adatnya yang sangat kental. Di Pelaw inilah dikenal acara Aroha dan maatenu. Aroha adalah perayaan maulid Nabi Muhammad saw ala negeri Pelay (Islam Adat), ia agak berbeda dengan negeri-negeri Islam lainnya, di mana pada umumnya perayaan mauled dilaksanakan secara massal oleh negeri, tetapi di Pelaw selain perayaan secara massal oleh negeri, masing-masing soa juga melaksanakan aroha, dan aroha dilaksanakan secara meriah sepanjang bulan rabiul awal. Pelaksanaan aroha di Pelaw dilakukan untuk memaknai dua momentum penting, yakni kelahiran dan wafatnya nabi Muhammad saw. Maatenu disebut juga cakalele. Merupakan ritual yang berhubungan dengan perang. Pelaksanaannya dilakukan sekali dalam tiga tahun. Peserta maatenu memperlihatkan kekebalan atau ketangkasan mereka dalam berperang. Maatenu diikuti oleh anak-anak negeri yang berada di kampong halaman maupun mereka yang ada diperantauan. Peserta maatenu dipersiapkan secara khusus pada soa dan rumah tua masing-masing. Prosesi persiapan smpai pada pelaksanaan ritual maatenu penuh dengan simbolsimbol, baik berupa benda-benda atau alat yang digunakan dalam ritual, konstum, lakon atau gerak tertentu maupun mantra-mantra dan syarat-syarat khusus yang berlaku.Namun yang menjadi masalah adalah danya dua identidas keberagamaan mereka, yakni muslim yang panatik kepada Islam Syariat dan muslim yang panatik kepada adat leluhur, sehingga di Pelaw dikenal istilah Islam Syariat dan Islam Adat. Kedua komunitas se-muslim ini mengalami konflik berkepanjangan. Pada tahun 1939 adalah puncak ketengangan antara Islam Syariat dengan Islam Adat. Pada tahun itu, Islam adat mengusir Islam Syariat. Pengusiran itu dirasakan dan dialami langsung oleh Husain Tuasikal yang masih bersusia muda (belum menikah). 
Dikisahkan oleh para informan (seperti Sulaikha Latuconsina dan Abdul Khalik Latuconsina) bahwa pada tahun 1939, Islam adat mengusir Islam Syariat dari negeri Pelaw. Pengusiran itu terjadi karena kekhawatitan kaum adat akan perkembangan Islam syariat yang sagat pesat. Kaum adat khawatir akan tiba saatnya mereka akan tersudut, dan sebelum semua itu terjadi, lebih baik mendahului dari pada didahului. Dalam pengusiran itu, rumah penganut Islam Syariat dibakar, orangorangnya diusir bahkan ada beberapa diantara mereka yang terbunuh. Termasuk Husain Tuasikal ikut terbantai. Pada pagi hari, tubuh Husain Tuasikal ditemukan dipantai oleh seorang pembantu papa Raja Kariu bernama Maria. Ia dalam keadaan pingsang dengan luka disekujur tubuhnya. Tidak diketahui secara pasti siapa pelakunya, yang jelas dari Islam Adat yang mengusir mereka. Maria yang menemukanya melapor ke Papa Raja Kariu dan mereka memberikan pertolongan kepada Husian Tua sikal. Beberapa hari Husian Tuasikal dirawat Papa raja Kariu, dan setelah sembuh Husian Tusaikal dibawa ke Kailolo bersama dengan Islam Syariat yang lainnya. Dalam pengungsian di Kailolo yang berlangusng sekitar 3-5 bulan, kemudian mereka bersepakat untuk pindah menjauh dari muslim adat. Dipilihlah kampung Ory sebagai tempat baru mereka. Kampung Ory hanya berjarat sekitar 4 $\mathrm{km}$ dari Pelaw di antarai oleh Negeri Kariu (negeri Nasrani), namun kampung Ory tetap dalam wilayah negeri Pelaw.

Setelah keadaan merasa aman di kampung Ory, Husein Tuasikal tumbuh menjadi pemuda yang bersahaja, selain kedalaman akan ilmu agama yang telah dimiliki karena belajar di Kailolo pada guruguru yang pernah mukim di Mekah, juga pernah sekolah di Ambon, sekolah Mahasinul Khaliqin. Kejujuran dan ketawaduannya mengundang sipatik dan disegani oleh kawan maupun lawan. Perangai tersebut menjadi dambaan gadis remaja seusianya. Di umur yang ke-24 tahun, tepatnya tahun 1942, Husein Tuasikal melamar dan mengawini seorang gadis yang bernama Rokaiyah Latuconsina. Dari perkawinan ini, mereka dikaruniai lima orang anak, yaitu: 1) Abd. Gani Husain Tua Sikal (alumni s1 Fakultas Syariah IAIN Surabaya) alm, 2) Farida Husain Tua Sikal (Sarjana Muda Fakultas usulhuddin IAIN Alauddin Makassar) alm, 3) Najib Husain Tua Sikal (Alumni S1 Fakultas Tarbiyah STAIN Ternate) alm, 4) Sulaikha Husain Tua Sikal (sarjana muda Faukultas Tarbiyah IAIN Malang), dan 5).Ghazali Husain Tua Sikal (syariah iain Surabaya sunan ampel) alm.

\section{Pendidikan dan Politik}

Walaupun sudah menikah dan memiliki anak, kegigihannya dalam menunut ilmu tidak diragukan, ini dibuktikan sambil berkebun ia juga masih tetap aktif belajar kitab di Kailolo. Setelah belajar di Kailolo, iapun kembali ke Ory dan mengajar agama ke tetangga dalam bentuk majelis taklim.

Kegiatan ini dimulai dengan bentuk membaca doa bersama (tahlilan) pada setiap malam jum'at. Selesai berdoa, biasanya dilakukan dengan membahas kitab agama (Tafsir, hadits dan fiqih) bertempat di Mushalla/ Masjid di Tunimahu. Pesertanya adalah keluarga, masyarakat sekitar Tunimahu dan Ory. Kemudian berkembang menjadi kajian khusus setiap selesai shalat Ashar dua kali dalam seminggu. Bentuk lainnya adalah menjadi tempat bertanya bagi masyarakat yang merasa tidak atau kurang memahami masalah-masalah yang muncul dalam ibadah dan hukum-hukum fiqh di luar ibadah.

Sejak awal, Husain Tuasikal merupakan murid kesayangan dari seorang ulama besar di Kailolo, Haji Abdul Rahman Latuconsina. Selain karena Husain Tuasikal adalah merupakan kerabat dekat, juga karena pada diri Husain Tuasikal ada kesungguhan dalam mengembangkan agama Islam, khususnya dalam bidang pendidikan. Haji Abrurrahman Tuasikal adalah seorang Mukimin (tinggal di Mekah), namun sering pulang ke Pulau Haruku. Di Masa tua sang guru, ia banyak mengirimkan kitabkitabnya ke Husain Tuasikal. Sampai akhirnya Haji Abdul Rahman Latuconsina meninggal di Mekah, diamanahkan untuk semua kitab-kitabnya dikirim ke Husain Tuasikal di Maluku untuk dipergunakan.

Menjadi juru dakwah di sebagian wilayah Maluku Tengah, dimulai ketika kajian-kajian agama itu diikuti oleh orangtua siswa yang berasal dari luar Tunimahu (Ory), maka ketika mereka kembali ke kampungnya masing-masing, mengundang Husain TYuasikal untuk berceramah agama atau mengkaji kitab-kitab agama. Terutama di desa; Iha, Sirisori Islam dan desa Kulur Kecamatan Saparua, dan sebagian dari Wilayah Seram Bagian Timur. Ketika alumni PGA yang kemudian menjadi Guru 
di berbagai desa yang ada Maluku Tengah, maka kegiatan dakwah dan pengajian Husain Tuasikal ini semakin meningkat.

Semangat dan Ketekunan beliau dalam berdakwah sangat mengagumkan, beliau mendatangi desa-desa Islam untuk berdakwah/ berceramah dengan menggunakan perahu layar (ukuran kecil) yang sering dihadang gelombang dan hujan tetapi beliau terus beraktivitas. Kedaan ini berlangsung sampai pada akhir tahun 1970 an. Setelah akhir 1970 an kegiatan berdakwah ke desadesa Islam dilakukan dengan menumpang kapal motor sejalan dengan dinamika perkembangan transportasi kelautan di wilayah Maluku. Dari kegiatan Dakwah dan kajian-kajian agama, dan menyebarnya alumni Nadil Ulum di wilayah Maluku Tengah, maka Husain Tuasikal mulai membuka cabang lembaga Pendidikan Nadil Ulum di beberapa desa Islam.

\section{RMS: salah satu rintangan}

Dakwah dalam bentuk pengajian majlis taklim tidak semulus yang diharapkan, kekacauan ada di mana-mana. Saat kemerdekaan baru saja diproklamirkan di Jawa, di Maluku juga ada Republik Maluku Selatan (RMS) (Rukmy, 2006) yang ingin mendirikan sebuah negara, mereka ini menteror bagi siapa saja yang tidak seideologi dengan mereka. Husein Tuasikal adalah salah satu incaran RMS, ia dicari dan keluarganyapun diintimidasi. Kelakuan RMS terhadap keluarga Tuasikal, karena Husein Tuasikal bersama Letnan Kadir Tuakia mendirikan sebuah Organisasi PRIMA (Pemuda Republik Indonesia Maluku) dimana Husain Tuasikal sebagai sekteraris dan letnan Kadir Tuakia sebagai ketua organisasi tersebut. Karena ia dicari dan diancam akan dibunuh oleh RMS, Husein Tuasikal lari ke hutan di Pulau Seram untuk bersembunyi. Jejaknya tak tercium oleh RMS. Segala cara dilakukan RMS untuk menangkapnya, namun tak berhasil. Jalan terakhir yang dilakukan RMS adalah menangkap bapak kandung dan saudara perempuannya untuk dipenjara di Ambon. Ini dilakukan agar Husain Tuasikal keluar dari hutan dan menyerahkan diri untuk membebaskan keluarganya. Taktik RMS ini ternyata ampuh, setelah beberapa hari bapak dan saudaranya dipenjara dan disiksa di Ambon, Husain Tuasikal menyerahkan diri ke RMS di Ambon. Husain Tuasikal dipenjara oleh RMS di Ambon sekitar dua tahun lamanya (tahun 1950-1952).

\section{Nadil Ulum: Lembaga Pendidikan Formal Pertama Haruku}

Setelah RMS berhasil ditumpas oleh TNI, semua tahanan RMS dibebaskan. Husein Tuasikal kembali ke Ory berkumpul bersama keluarganya. Karena desakan guru-gurunya yang bermukim di Mekah, terutama Abdul Rahman Marasabessi untuk membentuk sebuah lembaga pendidikan formal yang dapat menampung anak-anak Pulau Haruku yang beragama Islam, dimana lembaga pendidikan yang ada adalah bentukan Belanda yang lebih berorientasi kepada misi Kristen. Atas saran dari guru-gurunya dan dukungan dari keluarga besarnya tersebut, Husein Tuasikal mulai Merintis terbentuknya lembaga Pendidikan Islam di Ory pada tahun 1953, Lembaga Pendidikan Islam Nadil Ulumiddiyah Ory Maluku Tengah, yang terdiiri dari MI, PGA 4 Thn dan PGA 6 Thn. Perkembangan terakhir lembaga Pendidikan Nadil Ulum menjadi MI, M Ts dan MA sampai sekarang. Yayasan ini kemudian didirikan juga di beberapa desa di Maluku Tengah, sebagai berikut :

\begin{tabular}{cccc}
\hline No & Nama lembaga pendidikan & Jenjang Pendidikan & Tempat \\
\hline 1 & Nadil Ulmum I & $\begin{array}{c}\text { Madrasah Ibtidaiyah (MI), PGA 4 Th. } \\
\text { (Skrg M Ts), dan PGA 6 Th (skrg MA) }\end{array}$ & Ory Maluku Tengah \\
2 & Nadil Ulum II & Madrasah Ibtidaiyah (MI) & Iha, Saparua Maluku Tengah \\
3 & Nadil Ulum III & Madrasah Ibtidaiyah (MI) & SirisOry Islam, Saparua, Maluku Tengah \\
4 & Nadil Ulum IV & Madrasah Ibtidaiyah (MI) & Sepa, Seram Timur Maluku Tengah \\
5 & Nadil Ulum V & Madrasah Ibtidaiyah (MI) & Kabau, Pulau Haruku, Maluku Tengah \\
\hline
\end{tabular}

Pendirian cabang-cabang ini tidaklah semudah membalikkan tangan. Modal material yang sangat terbatas bukanlah pengahalang, yang penting bagi Husain Tuasikal adalah kemauan, dimana ada

kemauan di sana ada jalan. Selain kemauan yang kuat, ia juga sangat didukung oleh keluarganya. Bahkan pernah suatu waktu, keluarga besar beliau pergu ke Pulau Seram secara berombongan 
mencari kayu, yang mana kayu itu dijual untuk kepentingan pesantren. Bagi keluarga besarnya, tak perlu ada harta warisan, karena harta warisan keluarga besarnya sudah disumbangkan untuk keberlanjutan pesantren Nadil Ulum (Wawancara dengan Idris Latuconsina tanggal 26 Juni 2013). Dorongan dari keluarga dalam perjalanan sejarah sangat menentukan, sama halnya pada masa-masa awal perjuangan Rasulullah saw. Husain Tuasikal demikian adanya, ia Sangat didukung oleh keluarga ibu kandung (sarapiah) yakni tante dan om-omnya, mereka inilah yang menjadi penyumbang material pesantren. Adapun kesepuluh saudara-saudara ibu kandung Husain Tua Sikal dari orang tua $\mathrm{H}$ Kumbang (bapak) dan Baiharu (ibu) adalah:H. Abdul Rahman Latuconsina (nama Mekah) atau Kafraja (nama kampung), mukimin di Mekah dan banyak mengirimkan kitab dari sana ke Husain Tua sikal;, H. Abdul Khalik Latuconsina; H. Haitii Latuconsina; H. Abdul Haji Latuconsina; Sarapia Latuconsina; Lada Tomu Latuconsina; $\mathrm{H}$. Abdullah Latuconsina; H. Roh Ali Latuconsina; Hambali Latuconsina; dan Ahmad Latuconsina (Wawancara Abdul Khalik Latuconsina tanggal 2 Juli 2013).

Setelah Husain Tuasikal meninggal pada tanggal 28 Oktober 1982 (yang dimakamkan di pekuburan Islam Ory Negeri Pelaw Kecamatan Pulau Haruku), kaka estapek kepemimpinan Yayasan Nadil Ulum dijabat oleh: H. Idris Latuconsina (Sekretaris MUI Maluku sekarang), $\mathrm{H}$. Ghazali Husain Tuasikal (anak Husain Tuasikal), dan sekarang (karena H. Ghazali meninggal), maka sementara kendali yayasan berada di tangan wakilnya, Prof. Abdul Khalik Latuconsina. Adapun jenjang pendidikan di Cabang ORY, untuk Madrasan Ibtidaiyah berturut-turut dijabat Aminah Latuconsina Sunggi, Hj. Latifah Latuconsina, dan sekarang Mahmud Latuconsina. Madrasaj Tsanawiyah berturut-turut dijabat oleh Daud Latuconsina, H. Umar Latuconsina, Abdul Kadir Latuconsina,dan sekarang oleh Patirai Talauhu. Adapun jenjang Madrasah Aliyah berturut-turut dijabat oleh Najib Husain Tuasikal, Thahir Tuanaya, dan sekarang Mahmud Tuanaya.

Semasa hidup Husain Tuasikal, Nadil Ulum sebagai pesantren begitu tampak, yakni dangan adanya pengajian kitab kuning. Ada beberapa kitab kuning yang menjadi acuan di pesantren ini, antara lain: Tafsir Jalalain, Tafsir Al Azhar, Tafsir
Al Manar, Nailul Authar, Al Lu’lu wal Marjan, Riyadhushshalihin, Irsyadul Ibad, Fiqhussunnah, Tanwirul Qulub, shahih Bukhari Muslim, Sunan Abu Daud, dan lain-lain. Namun setelah Husain Tuasikal meninggal, aktifitas mengajian itu sudah mulai menurun. Sehingga nilai kepesantrenan ikut melemah yang ada sekarang di Nahil Ulum hanya ciri kemadrasah-an saja (Wawancara dengan Mahyuddin Latuconsina tanggal 28 Juli 2013).

Sistem Pengajaran yang diterapkan di semua jenjang Pendidikan baik MI, PGA 4 Tahun maupun PGA 6 Tahun,atau yang dirubah sekarang menjadi MI, MTs dan MA disesuaikan dengan kurikulum Departemen Agama. Siswa PGA 4 Tahun dan 6 Tahun berasal dari masyarakat Islam yang ada di Kecamatan Pulau Haruku, Kecamatan Saparua, dan Sebagian Wilayah Seram Timur (terutama dari Desa Latu, Hualoi, Ruta, dan Wae sapa). Lembaga Pendidikan saat itu tidak memiliki asrama, oleh Husain Tuasikal dititipkan pada sebagian warga masyarakat Tunimahu (Ory) yang berdiam di sekitar Lembaga Pendidikan, dan ada juga sebagian siswa yang dibangunkan rumah (tempat tinggal kecil) oleh orangtua siswa di lahan warga Tunimahu (Ory). Yang menarik adalah para Siswa yang tinggal di rumah warga atau yang membangun sendiri tempat tinggal, tidak membayar sesenpun kepada warga dan itu sesuai kesepakatan Ustadz Husain dengan warga serta orangtua siswa (Wawancara dengan Haidir tanggal 16 Juli 2013).Baru ketika lembaga Pendidikan Nadil Ulum di rubah menjadi Lembaga Pondok Pesantren, maka disediakanlah Asrama khusus untuk menampung siswa putra dan Putri yang berasal dari luar desa Ory dan Pelaw sampai sekarang.

Husain Tuasikal dikenal sangat tekun dan telaten mendidik siswa dalam ibadah, terutama mereka yang berasal dari luar desa Ory dan Pelaw, yang ditipkan pada warga masyarakat atau yang membangun tempat tinggal sendiri secara berkelompok, selalu dipantau untuk melaksanakan shalat Jamaah di Mushalla/ Masjid. Bahkan Setiap waktu shalat shubuh beliau harus membangunkan para siswa dari tempat tinggal mereka untuk shalat jamaah Subuh. Siswa yang tidak shalat jama’ah diberi sangsi dengan mengangkut pasir atau batu untuk kepentingan pembangunan pengembangan lembaga pendidikan.

Apa yang diperintahkan kepada santrisantrinya, terlebih dahulu dipraktekkan kepada 
anak-anaknya. Bila santri diwajibkan shalat jamaah, maka anak-anaknya pun menjadi contoh, Husain Tuasikal lebih keras lagi kepada anak-anaknya yang tidak berbuat demikian. Itulah sebabnya ia sangat disegani, karena ia berbuat lebih dahulu beru menyuruh orang lain. Pernah suatu ketika, anaknya (Sulaikha) tidak ikut shalat jamaah, dan setelah sampai di rumah anaknya tersebut menyuguhkan air panas, apa jawaban Husein Tuasikal? Jamuan air panas orang yang tidak shalat berjamaah sama dengan menjamu dengan darah babi. Ini adalah buulan bagi anaknya. Dalam mengajar anakanaknya Husain Tuasikal tidak terlalu banyak bicara, kalaupun bicara ia banyak memakai kata-kata kiasan. Baik keluarga maupun santri-santri, serta orang-orang kampong sangat segan kepada beliau, kita semua sungkan berjalan di depannya karena kharisma beliau (Wawancara dengan Sulaikha tanggal 4 Juli 2013).

Kegigihan, keuletan, dan keikhlasannya dalam mengembangkan pendidikan khususnya pendidikan agama, oleh Kemnterian agama Maluku mengajaknya untuk menjadi Pegawai Negeri. Ajakan itu direspon dengan baik Husein Tuasikal dengan mengikuri ujian guru agama sebagai persyaratan. Berkat keberhasilan dan prestasi Husein Tuasikal dalam dunia pendidikan, pada tahun 1978 ikut terpilih menjadi Guru teladan Nasional yang mewakili Propinsi Maluku.

\section{PENUTUP}

Husain Tuasikal adalah seorang Ulama dan tokoh pendidikan di Maluku, khususnya di Pulau Haruku. Beliau telah meninggalkan warisan berupa Yayasan Nadil Ulum yang mempunyai madrasah di lima negeri. Madrasah-madrasah tersebut masih eksis sampai sekarang. Sebagai lembaga pendidikan Islam tertua di Pulau Haruku, madrasah dibawah naungan Nadil Ulum telah banyak menelorkan alumni yang sampai sekarang banyak yang eksis di tengah masyarakat. Selain sebagai tokoh pendidikan, beliau juga sebagai seorang pejuang kemerdekaan Republik Indonesia. Di masa mudanya beliau pernah menjadi pendiri sekaligus sekretaris PRIMA (Pemuda Republik Indonesia Maluku). Bagi beliau, merah putih atau NKRI adalah harga mati. Atas jasajasa beliau dalam mempertahankan merah putih di Maluku, beliau menjadi anggota Legiun Veteran Republik Indonesia. Liku-liku perjalanan beliau dalam bidang pendidikan dan mempertahankan NKRI, banyak suka dan duka, bagai mendayung menantang badai, menggapai ridha Ilahi.

\section{UCAPAN TERIMA KASIH}

Tulisan ini dapat selesai atas bantuan banyak pihak, penyusunan proposal , pengumpulan data, sampai dimuatnya dalam jurnal ini. Dari itu, penulis menyampaikan banyak terima kasih kepada Kepala Balai Penelitian dan Pengembangan Agama Makassar yang telah mengikutkan penulis dalam penelitian ini, juga saya sampikan ucapan terima kasih kepada keluarga almarhum Tuan Guru Tuasikal yang telah menerima penulis sebagai keluarga dan memberikan banyak informasi dalam tulisan ini, dan terakhir kepada redaksi jurnal AlQalam yang bersedia memuat tulisan ini.

\section{DAFTAR PUSTAKA}

Ahmad, Abd. Kadir. 2009. Ulama Bugis. Makassar: Penerbit Indobis Publishing.

Amal, M.Adnan. 2010. Kepulauan Rempah-Rempah Perjalanan Sejarah Maluku Utara 12501950. Jakarta: KPG (Kepustakaan Populer Gramedia).

Data Kementerian Agama Wilayah Provinsi Maluku tahun 2012.

Djubaeli, Dedi, dkk. 2011. Islam di Maluku: Studi Perkembangan Orang-Orang Keturunan Arab di Ambon dalam Persfektif Sosial Budaya. Ambon: Laporan Penelitian Lembaga Penelitian Institut Agama Islam Negeri Ambon (belum diterbitkan)

Gagas Ulung. 2011.Extremily Beautyful Maluku 125 Obyek Wisata Pailing Indah: Wsata Alam, bahari, Kuliner, Tradisi, dan Hotel. Jakarta: Gramedia Pustaka Utama dan Kompas Gramedia

Latuconsina, Abd. Khalik. 2009. Makna Simbolik Ritual Mảatenu dan Aroha di Negeri Pelaw Kecamatan Pulau Haruku. Ambon: Laporan Penelitian Institut Agama Islam Negeri Ambon.

Naya, A.Mujadid, dkk. 2011. Peta Dakwah di Kota Ambon. Ambon: Laporan Penelitian Lembaga Penelitian Institut Agama Islam Negeri Ambon. 
Rukmy. 2006. Apa dan Siapa RMS (Republik Maluku Selatan). Jakarta Timpani Publishing.

Rumahuru, Yance Zadrak. 2012. Islam Syariah dan Islam Adat Konstruksi Identitas Keagamaan dan Perubahan Sosial di Kalangan Komunitas Muslim Hatuhaha di Negeri Pelauw. Jakarta: Kementerian Agama RI.

Sunarto, Kamanto. 2004. Pengantar Sosiologi. Jakarta: Fakultas Ekonomi Universitas Indonesia. 